\title{
Genotoxicity evaluation of domestic sewage in a municipal wastewater treatment plant
}

\author{
Cesar Koppe Grisolia, Adriano Barros Barata de Oliveira, Helder Bonfim \\ and Maria de Nazaré Klautau-Guimarães \\ Universidade de Brasília, Instituto de Ciências Biológicas, Departamento de Genética e Morfologia, \\ Brasília, DF, Brazil.
}

\begin{abstract}
An evaluation of the genotoxicity of domestic sewage was carried out in a municipal wastewater treatment plant. The study was carried out using Allium cepa root tip cells through cytological parameters such as aberrant cells in anaphase-telophase and the mitotic index, and the fish species Oreochromis niloticus and Tilapia rendalli, through the index of micronuclei in peripheral erythrocytes. In the Allium test, each of the four stages of the wasterwater treatment routine was analyzed, i.e., crude sewage, primary effluent, secondary effluent, and tertiary effluent. $O$. niloticus and $T$. rendalli specimens were maintained in an aquarium continuously receiving the final effluent, in an open system, before being discharged into Lake Paranoá. For micronuclei analysis, blood samples were drawn after $7,21,60,102$ and 142 days, respectively, in controlled conditions. The numbers of aberrant cells found in the Allium test did not differ among the four stages tested, nor when compared with the control. At all stages, the most concentrated sample was more toxic than the respective diluted samples, as demonstrated by the decreased mitotic index. Different sampling of the same group of fish revealed no increase in the micronuclei frequency, regardless of the period of exposure. A correlation between long-term exposure and micronuclei induction was not found either.
\end{abstract}

Key words: Allium cepa, biomonitoring, domestic sewage, fish, micronuclei, mutagenicity.

Received: February 9, 2004; Accepted: August 4, 2004

\section{Introduction}

In Brasília, capital of Brazil, two wastewater treatment plants are capable of processing up to $95 \%$ of the produced domestic sewage at the tertiary level. Sludge from sewage plants is recovered to be used to improve the organic content of agricultural soils. At the same time, the final aqueous effluent is released into Lake Paranoá, a tropical reservoir, created in 1959 alongside the construction of the city of Brasília. Limnological analysis of Lake Paranoá showed a clear trophic gradient around the sites of effluent discharges. Lake Paranoá water is not used for drinking supply; nevertheless, the Municipal Drinking Water and Sewage Corporation has a continuous limnological monitoring program. As the city of Brasília has no chemical factories, nutrient input from domestic sewage defines the main source of pollution in Lake Paranoá. However, genotoxic compounds from other human activities may be disposed of in municipal sewers and end up in sewage

Send correspondence to Cesar Koppe Grisolia. Departamento de Genética e Morfologia, Instituto de Ciências Biológicas, Universidade de Brasília, 70910-900 Brasília, DF, Brazil. E-mail: grisolia@ unb.br. sludge (Jha et al., 1997). White and Rasmussen (1998) demonstrated that sanitary waters can contain a wide range of genotoxic substances, such as N-nitroso compounds, aromatic amines and poly-aromatic hydrocarbons (PAHs). A study carried out by Grisolia and Starling (2001) on micronuclei frequencies in fish from Lake Paranoá, under the influence of sewage treatment plant discharges, did not show evidence of mutagenicity. In Brazil, there have not been enough studies reporting results of on mutagenic evaluation of sewage and sludges from large wastewater treatment plants. Since in Brasília there are two methods of disposal, these studies were carried out in order to evaluate possible genotoxic contaminants at each stage of sewage treatment.

\section{Material and Methods}

Physicochemical analyses of sewage samples were carried out for all different stages of wastewater treatment, as a routine, by the Brasília Municipal Drinking Water and Sewage Corporation (CAESB). For each sewage sample collected for the mutagenicity studies, measurements of biochemical oxygen demand (BOD), chemical oxygen demand (COD), total suspended solid (TSS), total nitrogen 
(TN) and total phosphorus (TP) were done. The physicochemical profiles at the time of the current study were made once a month at the 4 different sites, from March 2000 through March 2002. The parameters analyzed represent the removal efficiency of the nutrients. The minimum and maximum values of each parameter obtained during that period are shown in Table 1. Wastewater treatment follows four stages: 1 . sand trapping and solid separation; 2 . primary sedimentation; 3 . biological oxidation with activated sludges; and 4 . final sedimentation and polyelectrolitic treatment with aluminum sulfate.

\section{Allium cepa study}

1. Crude sewage samples: domestic waste is received through a pipeline in the wastewater treatment plant. Effluent samples were diluted at $25 \%$ and $50 \%$ in filtered and dechloronized water. 2 . The primary effluent is the first step in the treatment in the grit chambers, to remove settleable and flotable materials from the wastewater. Treatment of the test onions was carried out at dilutions of $25 \%$ and $50 \%$. 3 . The secondary treatment reduces organic matter through the addition of oxygen, which provides an aerobic environment for microorganisms to biologically break down the remaining organic matter. The test onions were treated at dilutions of $25 \%$ and $50 \%$, and also with an undiluted (100\%) sample. 4. Tertiary level: the effluent of the secondary treatment process is discharged into the basins with aluminum sulfate, to remove remaining oil and grease by flotation. Test treatments were again carried out with samples diluted at $25 \%$ and $50 \%$ and an undiluted sample (100\%). In the treatment of $A$. cepa root cells, all sewage samples were used for $48 \mathrm{~h}$, within approximately $1 \mathrm{~h}$ of collection. For each test, $10 \mathrm{~A}$. cepa bulbs purchased from organic farmers were set up to produce roots in filtered and dechloronized tap water for two days and then transferred to the test solutions. Tap water was previously filtered in a bio-activated coal filter to remove chlorine and its byproducts commonly used for disinfecting drinking water. Two liters of water were aerated over a period of $24 \mathrm{~h}$ before filling the test tubes. Genotoxicity tests were then carried out with different concentrations of each sample. Prior to the genotoxicity test, growth inhibition tests were carried out for each sample, to find its toxicity level. During the treatment period, the samples were continuously shaken in a horizontal shaker. At the end of exposure, 5 to 6 root tips from each bulb were prepared for the microscopic slides. The root tips were fixed and macerated in a solution of $45 \%$ acetic acid ( 9 parts) and $1 \mathrm{~N} \mathrm{HCl} \mathrm{(1} \mathrm{part)} \mathrm{at}$ $50{ }^{\circ} \mathrm{C}$ for $10 \mathrm{~min}$, followed by squashing in $2 \%$ orcein stain in $45 \%$ acetic acid. Slides were prepared and examined under a light microscope. One hundred cells in anaphase or telophase were examined per onion and classified into the following categories, according to the chromosome aberrations presented: bridges, fragments and chromosome lagging, according to the modified protocol of Rank and
Nielsen (1993). All slides were coded and examined blind. The mitotic index was found by counting the mitotic cells at all stages per 1000 cells. Statistical analysis was performed using Mann-Whitney's $U$ test with $\alpha=5 \%$.

\section{Fish study}

Before being discharged, part of the final effluent from the tertiary treatment goes to an aquarium where its toxicity is biologically monitored. Wild Tilapia rendalli and Oreochromis niloticus specimens ranging from 15 to $20 \mathrm{~cm}$ in length were caught in Lake Paranoá to be used in this aquarium. Groups of $10 \mathrm{~T}$. rendalli and $10 \mathrm{O}$. niloticus specimens were maintained into the $3 \mathrm{~m}^{3}$ aquarium (open system). Blood samples were taken 7, 21, 60, 102 and 142 days thereafter, under controlled conditions. The blood samples were obtained with a syringe from gills and immediately smeared. This technique was chosen because it is suitable for these species and less damaging, and no mortalities followed blood sampling. Controls were obtained simultaneously with the experimental groups. The groups of $10 \mathrm{~T}$. rendalli and $10 \mathrm{O}$. niloticus specimens were captured by cast-nets, sampled and released back into the lake. Blood smears were fixed in methanol and Giemsa-stained. A total of 3,000 erythrocytes were examined for each fish under the light microscope. Only cells with intact cellular and nuclear membranes were scored. The criteria for identification of fish micronucleated erythrocytes were as follows: a) a MN should be smaller than one-third of the main nucleus; b) a MN must not touch the main nucleus; and c) a $\mathrm{MN}$ must not be refractive and should be the same color and intensity as the main nucleus. Mean MN frequencies, expressed as number of MN per 3,000 erythrocytes, were calculated for each exposure time. The $\mathrm{MN}$ frequencies obtained for each treatment time during the period of exposure were compared among samples and with the control, and statistically analyzed by Mann-Whitney's $U$-test $(\alpha=0.05)$. Fishes from Lake Paranoá were chosen for this study because the micronuclei frequencies were previously shown to be very low in all studied fishes, with no significant differences between the cleanest areas and the treated sewage discharge areas (Grisolia and Starling, 2001).

\section{Results}

Table 1 shows the values of the physicochemical parameters obtained for each sample collected for mutagenicity studies. These parameters are used in the monitoring of the efficiency of wastewater treatment, following standard recommendations of the USEnvironmental Protection Agency (www.epa.gov), and actually revealed the efficiency of the wastewater treatment plant. From crude sewage to final effluent, biochemical oxygen demand (BOD), chemical oxygen demand (COD), total suspended solid (TSS), total nitrogen (TN) and total phosphorus (TP) show that this procedure removed the or- 
Table 1 - Physicochemical analyses and characterization of settled sewage samples: Profile of wastewater treatment plant during the study sampling.

\begin{tabular}{lccccc}
\hline $\begin{array}{l}\text { Parameter } \\
(\mathrm{mg} / \mathrm{L})\end{array}$ & $\begin{array}{c}\text { Crude } \\
\text { sewage }\end{array}$ & Primary & Secondary & Tertiary & $\begin{array}{c}\text { Removal } \\
(\%)\end{array}$ \\
\hline BOD & $199-482$ & $177-317$ & $12-47$ & $2-13$ & 97 \\
COD & $458-815$ & $394-644$ & $42-85$ & $29-37$ & 95 \\
TSS & $70-303$ & $49-131$ & $4-13$ & $3-7$ & 97 \\
TN & $29.8-50.3$ & $34-49$ & $5.5-17.8$ & $4-15.3$ & 75 \\
TP & $5.3-11.7$ & $6.6-14.3$ & $0.8-2.4$ & $0.06-0.3$ & 97 \\
\hline
\end{tabular}

$\mathrm{BOD}=$ biochemical oxygen demand, $\mathrm{COD}=$ chemical oxygen demand, $\mathrm{TSS}=$ total suspended solids, $\mathrm{TN}=$ total nitrogen, $\mathrm{TP}=$ total phosphorus. Minimum - maximum values obtained during the sampled period.

ganic matter from the sewage. This does not mean, however, that toxic components in the sewage were removed.

The mitotic index in the root meristems grown in the negative control ranged from 9.2 to $12.2 \%$ (average $10.7 \%$ ). Table 2 shows the mitotic index values in root meristems grown in different concentrations of sewage from the four stages of wastewater treatment. The decrease in the mitotic index of the root tips reached statistical significance only in the highest tested concentrations of the secondary and tertiary stages. The cytogenetic aberrations most commonly observed in anaphase-telophase cells were bridges, fragments and chromosome lagging. Aberrant mitotic cells were counted and expressed as mean (and SD) of 10 onions. In the root meristems of the negative control, the percentage of aberrant cells ranged from 0.00 to $0.95 \%$ (average $0.40 \%$ ). Crude and primary sewage were not tested undiluted because of their high toxicity, as no growth was observed in the inhibition test. For both treatments, sewage was diluted only at $25 \%$ and $50 \%$ to find 1,000 anaphasetelophase cells (100 per onion). Sewage from secondary and tertiary stages was tested at $25 \%, 50 \%$ and undiluted $(100 \%)$. The mean frequency of aberrant cells did not differ statistically among the test samples nor from the control, in all four stages tested.

The results of the experiments with fish are shown in Figure 1. No altered nuclear or cellular morphology was observed in the analyzed erythrocytes. Cells were perfectly elliptical without cytoplasm vacuolization, indicating no cytotoxicity. Different sampling in the same fish group revealed no increase in micronuclei, regardless of the period of exposure. The maximum frequency of micronuclei registered was $1.75 \pm 0.85$, considering all the different periods of exposure. In the controls from Lake Paranoá, the frequencies of micronuclei were $1.5 \pm 0.6$ in Tilapia rendalli and $1.0 \pm 0.8$ in Oreochromis niloticus. The micronuclei

Table 2 - Allium cepa anaphase-telophase chromosome aberration assay carried out in different stages of a wastewater treatment plant. Numbers represent mean and SD in 10 onions analyzed per treatment.

\begin{tabular}{|c|c|c|c|c|c|c|}
\hline Treatment plant & Bridge & Fragment & $\begin{array}{c}\text { Chromosome } \\
\text { lagging }\end{array}$ & $\begin{array}{c}\text { Total of } \\
\text { aberrant cells }\end{array}$ & $\begin{array}{l}\text { N. of cells } \\
\text { examined }\end{array}$ & $\begin{array}{c}\text { Mitotic index } \\
(\%)\end{array}$ \\
\hline Water & - & - & $0.4 \pm 0.5$ & $0.4 \pm 0.5$ & 1,000 & $10.7 \pm 1.5$ \\
\hline MMS & $3.0 \pm 3.8$ & $1.3 \pm 1.9$ & $1.4 \pm 2.4$ & $5.7 \pm 7.5$ & 1,000 & $4.9 \pm 1.5$ \\
\hline \multicolumn{7}{|l|}{ Crude effluent } \\
\hline $50 \%$ & $0.2 \pm 0.4$ & $0.2 \pm 0.4$ & $0.9 \pm 0.7$ & $1.3 \pm 0.9$ & 1,000 & $5.0 \pm 1.7$ \\
\hline $25 \%$ & - & $0.1 \pm 0.3$ & $0.6 \pm 0.8$ & $0.7 \pm 0.8$ & 1,000 & $4.1 \pm 1.0$ \\
\hline \multicolumn{7}{|l|}{ Primary effluent } \\
\hline $50 \%$ & - & $0.3 \pm 0.4$ & $1.4 \pm 1.5$ & $1.7 \pm 1.5$ & 1,000 & $4.5 \pm 1.1$ \\
\hline $25 \%$ & - & - & $0.9 \pm 1.1$ & $0.9 \pm 1.1$ & 1,000 & $4.4 \pm 1.3$ \\
\hline \multicolumn{7}{|c|}{ Secondary treatment } \\
\hline $100 \%$ & - & - & $0.1 \pm 0.3$ & $0.1 \pm 0.3$ & 945 & $3.1 \pm 1.3^{*}$ \\
\hline $50 \%$ & - & - & $1.0 \pm 1.3$ & $1.3 \pm 1.3$ & 1,000 & $5.4 \pm 0.9$ \\
\hline $25 \%$ & - & - & $0.2 \pm 0.4$ & $0.2 \pm 0.4$ & 1,000 & $4.7 \pm 0.9$ \\
\hline \multicolumn{7}{|l|}{ Tertiary treatment } \\
\hline $100 \%$ & - & - & - & - & 824 & $2.7 \pm 1.0^{*}$ \\
\hline $50 \%$ & - & - & $0.2 \pm 0.4$ & $0.2 \pm 0.4$ & 960 & $4.6 \pm 1.2$ \\
\hline $25 \%$ & - & - & $0.4 \pm 0.9$ & $0.4 \pm 0.9$ & 1,000 & $5.1 \pm 1.6$ \\
\hline
\end{tabular}

*Statistically significant, $\mathrm{p}<0.05$. 


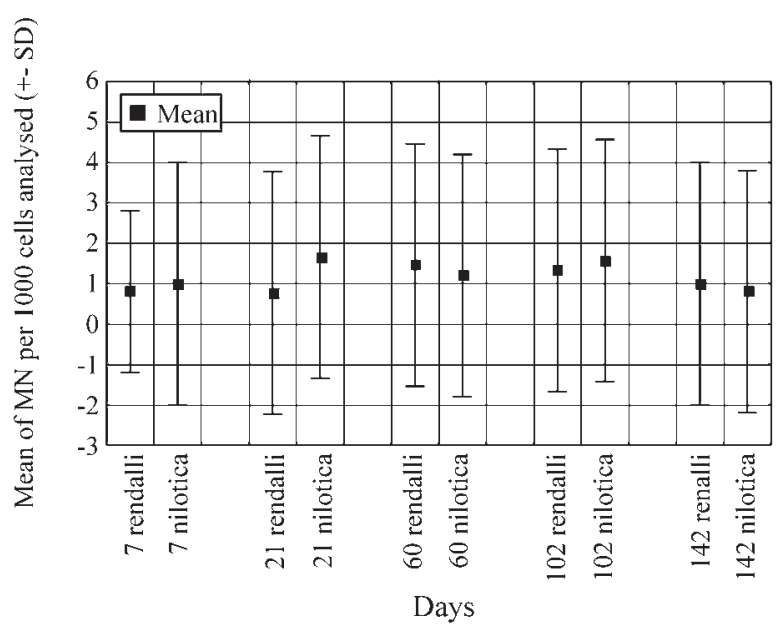

Figure 1 - Mean micronucleus frequencies in $O$. niloticus and T. rendalli after 142 days of maintenance in the wastewater treatment tanks. MN frequencies did not differ statistically from the fish living in Lake Paranoá (Mann-Whitney $U$ test, $\mathrm{p}>0.05$ ).

frequencies observed in the blood samples from the fishes of the aquarium did not differ from the controls $(p>0.05)$.

\section{Discussion}

Due to the discharge of treated sewage into rivers and lakes, there is concern that genotoxic chemicals may harm organisms in the ecosystems as well as humans, by accumulation in the food chain. A survey on sludge samples from 34 cities in the United States did not highlight any significant association of mutagenicity with wastewater treatment procedure (Babish et al., 1983). On the other hand, there are also studies reporting that extracts of wastewater sludges from various American cities were found to be mutagenic in the Ames Salmonella typhimurium test (Mumma et al., 1988; Blevins and Brennan, 1990; Brown et al., 1991). White and Rasmussen (1998) presented data showing that, in large metropolitan areas, municipal wastewaters are a complex mixture of wastewater from industrial and domestic sewages, containing a wide range of substances from a variety of sources. The Allium cepa test for genotoxicity has been used on wastewater from different sources, such as industrial and domestic (Somashekar $e t$ al., 1985; Nielsen and Rank, 1994; Smaka-Kincl et al., 1996; Rank and Nielsen, 1998). In marine and freshwater ecosystems, micronuclei counts have been widely used to monitor genotoxic compounds in water. Several fish species have been reported to be good targets for in situ biomonitoring of rivers and lakes through the micronucleus test (Minissi et al., 1996; Hayashi et al., 1998; Grisolia and Starling, 2001; Rodriguez-Cea et al., 2003). Tilapia rendalli and Oreochromis niloticus have been revealed to be suitable bio-indicator species for the detection of mutagens in water by the micronucleus test (Grisolia and Cordeiro, 2000).
In this study, the Allium root anaphase-telophase assay demonstrated that the most concentrated samples were more toxic than their respective diluted samples. In some treated samples, the mitotic index was so low that it was not possible to get 100 anaphase-telophase cells per onion to count chromosome aberrations. Thus, when the final effluent of the wastewater treatment plant is heavily diluted in the lake, these toxic effects can be limited. Smaka-Kincl et al. (1996) showed that the sewage treatment procedure at the tertiary level causes a statistically significant decrease in the amount of chromosomal aberrations in A. серa. The present study with fish allowed us to follow the same fishes over time. The first sample was obtained at the seventh day of exposure, without an acclimatization period. However, the last sample was taken after a long-term exposure (142 days). A correlation between long-term exposure and micronuclei induction was not found. The absence of significant genotoxicity in the sewage may conceivably indicate a minor genotoxic risk. Genotoxicity studies of sludge from a wastewater treatment plant in Rome, carried out by Ottaviani et al. (1993) using Salmonella typhimurium, gave negative results. On the other hand, Hopke et al. (1982; 1984) demonstrated the occurrence of mutagenic compounds in some municipal sewage sludges, mainly from plants with industrial effluents. Thus, in view of the application on agricultural land, it would be interesting to extend this study to include the sludge applied. The A. серa and fish assays give information of clastogenicity and spindle effects. Other endpoint effects, such as point mutation, should also be investigated.

\section{Acknowledgements}

The authors thank the Brasília/DF Municipal Drinking Water and Sewage Corporation (CAESB) for providing field facilities. This research received financial support from the University of Brasília (UnB).

\section{References}

Babish JG, Johnson BE and Lisk DJ (1983) Mutagenicity of municipal sewage sludge of American cities. Environ Sci Technol 17:272-277.

Blevins RD and Brennan LA (1990) Fate of mutagenic activity during conventional treatment of municipal wastewater sludge. Arch Environ Toxicol 19:657-664.

Brown KW, Thomas JC and Donelly KC (1991) Bacterial mutagenicity of municipal sewage sludges. J Environ Sci Health 26:359-413.

Grisolia CK and Cordeiro CMT (2000) Variability in micronucleus induction with different mutagens applied to several species of fish. Genetics and Molecular Biology 23:235-239.

Grisolia CK and Starling FLRM (2001) Micronuclei monitoring of fishes from Lake Paranoá, under influence of sewage treatment plant discharges. Mutation Res 491:39-44.

Hayashi M, Ueda T, Uyeno K, Wada K, Kinae N, Saotome K, Tanaka N, Takai A, Sasaki YF, Asano N, Sifuni T and Ojima 
Y (1998) Development of genotoxicity assay systems that use aquatic organisms. Mutation Res 399:125-133.

Hopke PK, Plewa MJ, Johnston JB, Weaver DL, Wood SG, Larson RA and Hinesly T (1982) Multitechnique screening of Chicago municipal sewage sludge for mutagenic activity. Environ Sc Technol 16:140-147.

Hopke PK, Plewa MJ, Stapleton PL and Weaver DL (1984) Comparisons of the mutagenicity of sewage sludges. Environ Sci Technol 18:909-916.

Jha NA, Hutchinson TH, Macklay JM, Elliot BM and Dixons DR (1997) Evaluation of the genotoxicity of muncipal sewage effluent using the marine worm Platynereis dumerilli (Polychaeta: Nereidae). Mutation Res 391:179-188.

Minissi S, Ciccotti E and Rizzoni M (1996) Micronucleus test in erythrocytes of Barbus plebejus (Teleostei, Pisces) from two natural environments; a bioassay for the in situ detection of mutagens in freshwater. Mutation Res 367:251-254.

Mumma RO, Rashid KA, Raupach DC, Shane BS and Scarlet-Kranz JM (1988) Mutagens, toxicants and other constituents in small cities' sludges in New York State. Arch Environ Contam Toxicol 17:657-663.

Nielsen MH and Rank J (1994) Screening of toxicity and genotoxicity in wastewater by the use of the Allium test. Hereditas 121:249-254.
Ottaviani M, Crebelli R, Fuselli S, La Rocca C and Baldassarri LT (1993) Chemical and mutagenic evaluation of sludge from a large wastewater treatment plant. Ecotoxicol and Environ Safety 26:18-32.

Rank J and Nielsen MH (1993) A modified Allium test as a tool in the screening of genotoxicity of complex mixtures. Hereditas 118:49-53.

Rank J and Nielsen MH (1998) Genotoxicity testing of wastewater using the Allium cepa anaphase-telophase chromosome aberration assay. Mutation Res 418:113-119.

Rodriguez-Cea A, Ayllon F and Garcia-Vasquez E (2003) Micronucleus test in freshwater fish species: an evalutation of its sensitivity for application in field surveys. Ecotoxicol and Environ Safety 56:442-448.

Smaka-Kincl V, Stegnar P, Lovka M and Toman MJ (1996) The evaluation of waste, surface and ground water quality using the Allium test procedure. Mutation Res 368:171-179.

Somashekar SK and Gurudev MR (1985) Cell abnormalities induced by manufacturing industry waste water. Cytologia 50:129-134.

White P and Rasmussen JB (1998) The genotoxic hazard of domestic wastes in surface waters. Mutation Res 410:223-236.

Associate Editor: Carlos F. M. Menck 